\title{
Intestinal Graft-versus-Host Disease Is Initiated by Donor T Cells Distinct from Classic Cytotoxic T Lymphocytes
}

\author{
Dwain L. Thiele, Marsha L. Eigenbrodt, Susan E. Bryde, Edwin H. Eigenbrodt, and Peter E. Lipsky \\ Departments of Internal Medicine and Pathology, University of Texas Southwestern Medical Center at Dallas, Dallas, Texas 75235
}

\begin{abstract}
In these studies, the role of $\mathbf{T}$ helper and $\mathbf{T}$ cytotoxic cells in generating intestinal graft-vs.-host disease (GVHD) was examined. Treatment of C57BL/6J (B6) splenocytes with L-leucyl-L-leucine methyl ester (Leu-Leu-OMe) selectively removes natural killer cells, cytotoxic T lymphocyte (CTL) precursors, and the capacity to cause lethal GVHD in irradiated B6xDBA/2 F1 (B6D2F1) mice while preserving $T$ helper cell function. Neither control nor Leu-Leu-OMe-treated DBA/2 donor spleen and bone marrow cells were found to induce lethal GVHD in B6D2F1 recipients. However, extensive colonic GVHD developed in B6D2F1 recipients of DBA/2 bone marrow and spleen cells. Enteropathic GVHD in DBA/ $2 \rightarrow$ B6D2F1 mice was reduced in severity after anti-L3T4 $+\mathrm{C}$ treatment of donor cells, and was eliminated by anti-Thy1.2 $+C$ or the combination of anti-L3T4 and anti-Lyt $2+C$ treatment of the donor cell inoculum. However, neither antiLyt2 + C, Leu-Leu-OMe, nor anti-Lyt $2+C$ and Leu-LeuOMe treatment of donor cells significantly decreased severity of gut GVHD. Leu-Leu-OMe treatment of DBA/2 or B6 SpC was comparably effective in preventing in vitro or in vivo generation of B6D2F1-specific CTL. These findings, therefore, demonstrate that histologically severe enteropathic GVHD does not require participation of CTL and is not always associated with high mortality rates.
\end{abstract}

\section{Introduction}

Transfer of $\mathrm{T}$ cells to allogeneic, immunocompromised hosts causes graft-vs.-host disease (GVHD) (1-5). ${ }^{1}$ This syndrome is associated with lesions of the skin, liver, intestinal tract, and lymphoid organs and is a major cause of morbidity and mortality following bone marrow transplantation $(6,7)$. The specific $\mathrm{T}$ cell functions that are required to initiate or propagate various aspects of this syndrome have not been clearly defined (8). The clinical manifestations of GVHD induced by transfer

Address reprint requests to Dr. Thiele, Department of Internal Medicine, University of Texas Southwestern Medical Center, 5323 Harry Hines Boulevard, Dallas, TX 75235-8887. 1989.

Received for publication 4 May 1989 and in revised form 15 August

1. Abbreviations used in this paper: BMC, bone marrow cell; CTL, cytotoxic T lymphocyte; FBS, fetal bovine serum; GVHD, graft-vs.host disease; Leu-Leu-OMe, L-leucyl-L-leucine methyl ester; NK, natural killer (cell); SpC, spleen cell.

J. Clin. Invest.

(c) The American Society for Clinical Investigation, Inc. $0021-9738 / 89 / 12 / 1947 / 10 \$ 2.00$

Volume 84, December 1989, 1947-1956 of $\mathrm{T}$ cells that recognize only class I major histocompatibility complex (MHC) antigens, class II MHC antigen alone, or non-MHC antigen disparities have been noted to differ (8-11). Moreover, the spectrum of lesions induced by CD4( +$)$ and $\mathrm{CD} 8(+) \mathrm{T}$ cell subsets has also been noted to differ. Despite the differences, however, considerable overlap in the features of GVHD induced in these various situations is also apparent (8). The fact that both $\mathrm{CD} 4(+)$ and $\mathrm{CD} 8(+) \mathrm{T}$ cell subsets can give rise to cytotoxic T lymphocytes (CTL) and produce lymphokines when stimulated with appropriate class II or class I MHC antigens (12-16) may explain the many common features of GVHD induced by specific histocompatibility antigen disparities or from phenotypically distinct $T$ cell subsets.

Previous studies in our laboratory have noted that lethal GVHD induced in irradiated B6D2F1 (H-2 $\left.2^{b, d}\right)$ mice by transfer of B6 (H-2 $)$ parental bone marrow cells (BMC) and spleen cells $(\mathrm{SpC})$ is prevented by a brief preincubation of donor cells with L-leucyl-L-leucine methyl ester (Leu-LeuOMe) $(17,18)$. Exposure of human or murine lymphocytes to Leu-Leu-OMe results in depletion of all natural killer (NK) cells and a fraction of $T$ cells $(18,19)$. After exposure to this agent, $B$ cells and $\mathrm{T}$ helper cells are largely preserved, whereas the capacity to generate CTL from both CD4(+) or CD8(+) subsets is ablated $(18,19)$. Thus, the salutary effect of LeuLeu-OMe treatment of donor cells on the course of GVHD in B6 $\rightarrow$ B6D2F1 mice suggests that cytotoxic lymphocytes play an essential role in the evolution of GVHD in this class I + II $\mathrm{MHC}$ antigen and multiple non-MHC antigen disparate strain combination. Furthermore, inasmuch as depletion of CD4(+) T cells, CD8( + ) $\mathrm{T}$ cells, or NK cells alone does not prevent lethal GVHD in this strain combination $(17,18)$, these findings demonstrated that Leu-Leu-OMe treatment of donor cells offers a unique approach to prevention of this complication of bone marrow transplantation.

A number of investigators have noted that transfer of DBA/2 as opposed to B6 parental spleen cells into unirradiated $\mathrm{B} 6 \mathrm{D} 2 \mathrm{~F} 1$ mice results in distinctively different patterns of GVHD (20-23). DBA/2 $\rightarrow$ B6D2F1 mice develop an alloproliferative syndrome which has been attributed to the helper effects of alloreactive DBA/2 CD4(+) donor cells (20-23). The effects of transferring DBA/2 SpC into irradiated B6D2F1 have not been studied as extensively, nor has the nature of the effector cells inducing GVHD.

The current studies were, therefore, undertaken to examine the clinical manifestations of GVHD in this strain combination and the role of CTL in the induction of this syndrome. It was found that transfer of DBA/2 BMC and SpC to irradiated B6D2F1 mice rarely led to lethal GVHD. However, intestinal GVHD was readily apparent in B6D2F1 recipients of DBA/2 BMC and SpC. Treatment of the donor inoculum with Leu-Leu-OMe had no effect on the evolution of intestinal GVHD in this strain combination. These findings demonstrate that histologically severe enteropathic GVHD does not 
require the participation of CTL and is not always associated with high rates of mortality.

\section{Methods}

Mice. C57BL/6J (B6), (C57BL/6JxDBA/2J)F1(B6D2F1), and DBA/2J (DBA/2) female mice were purchased from the Jackson Laboratory, Bar Harbor, ME.

Medium. RPMI 1640 (Hazleton Research Products, Denver, PA), supplemented with $5 \mathrm{mM}$ Hepes, $1 \mathrm{mM}$ sodium pyruvate, $5 \times 10^{-5} \mathrm{M}$ 2-mercaptoethanol, penicillin $\mathrm{G}(200 \mathrm{U} / \mathrm{ml})$, gentamicin $(10 \mu \mathrm{g} / \mathrm{ml})$, and L-glutamine $(0.3 \mathrm{mg} / \mathrm{ml})$, was used for cell cultures. When used in cytotoxicity assays, medium was supplemented with $10 \%$ fetal bovine serum (FBS, Hazleton Research Products), whereas medium was supplemented with $2 \%$ human serum for use in mixed lymphocyte cultures.

Antibodies. Anti-Thy1.2 (HO-13-4), anti-L3T4 (GK1.5), antiLyt-2 (3.155), anti-Lyt2.2 (HO2.2), and anti-Lyt 2.1 (116-13.1) were culture supernatants or ascitic fluid produced from hybridoma cells obtained from the American Type Culture Collection, Rockville, MD (24-28).

Rat concanavalin A (Con A) supernatant. Rat (Sprague-Dawley, Sasco Inc., Omaha, NE) spleen cells $\left(10^{7} / \mathrm{ml}\right)$ were suspended in medium supplemented with $10 \% \mathrm{FBS}, 20 \mu \mathrm{g} / \mathrm{ml}$ of Con $\mathrm{A}$, and $10^{-9} \mathrm{~g} / \mathrm{ml}$ 4 $\beta$-phorbol 12-myristate-13-acetate (Sigma Chemical Co., St. Louis, $\mathrm{MO}$ ) for $4 \mathrm{~h}$ at $37^{\circ} \mathrm{C}$ in $95 \%$ air, $5 \% \mathrm{CO}_{2}$ atmosphere. Rat spleen cells were then washed twice with Hanks' balanced salt solution (HBSS) supplemented with $0.1 \mathrm{M}$ methyl $\alpha$-D-mannopyranoside (Sigma Chemical Co.) and then twice more with HBSS. Spleen cells were then resuspended $\left(10^{7} / \mathrm{ml}\right)$ in medium supplemented with $10 \%$ FBS and cultured for $24 \mathrm{~h}$ before collection of cell-free culture supernatant.

EL4 supernatant. Cells from the EL4.IL2 subline of the murine EL4 lymphoma line $\left(10^{7} / \mathrm{ml}\right.$, American Type Culture Collection) were cultured with $20 \mathrm{ng} / \mathrm{ml}$ phorbol dibutyrate in medium supplemented with $10 \%$ FBS for $24 \mathrm{~h}$. Cell-free culture supernatant was then harvested and extensively dialyzed (10,000-mol wt exclusion membranes) to remove excess phorbol dibutyrate before use in cell cultures.

Cell preparation. Femurs and tibias were dissected free of muscle and connective tissue, crushed with a sterile porcelain mortar and pestle, and then filtered through sterile nylon mesh. BMC were then washed with HBSS. Spleens were minced and filtered through sterile nylon mesh and the SpC were then washed with HBSS. For depletion of Thy 1.2(+), L3T4(+), or Lyt2(+) cells, BMC or SpC were suspended at a concentration of $20-40 \times 10^{6} / \mathrm{ml}$ in RPMI 1640 supplemented with $25 \mathrm{mM}$ Hepes, $10^{-4} \mathrm{M}$ 2-mercaptoethanol, and $0.3 \%$ bovine serum albumin (Sigma Chemical Co.). Anti-Thy1.2, anti-L3T4, antiLyt2, and anti-Lyt2.2 or anti-Lyt2.1 MAbs were added and the cell suspensions were incubated at $4^{\circ} \mathrm{C}$ for $30 \mathrm{~min}$ before the addition of a 1:8 dilution of rabbit complement (Pel Freez, Rogers, AR) previously adsorbed with mouse spleen cells. Cells were then incubated at $37^{\circ} \mathrm{C}$ for $50 \mathrm{~min}$. In experiments in which L3T4(+) or Lyt2(+) cells were being removed, cells were then pelleted and fresh medium, antibody, and complement were added before a second incubation at $37^{\circ} \mathrm{C}$ for $50 \mathrm{~min}$. After antibody and complement treatment, cells were again filtered through sterile nylon mesh and then washed two times in HBSS. After treatment with appropriate MAb $+\mathrm{C},<1 \%$ residual Thy 1.2(+), L3T4(+), or Lyt2(+) cells could be detected by flow cytometric analysis (18).

Incubation with Leu-Leu-OMe. Leu-Leu-OMe was synthesized from leucyl-leucine (Sigma Chemical Co.) as described (29). Cells were washed and were suspended $\left(2.5-10 \times 10^{6} / \mathrm{ml}\right)$ in PBS and were incubated for $15 \mathrm{~min}$ at room temperature with the indicated concentration of Leu-Leu-OMe. Cells were then washed, were resuspended in culture medium, and were placed in culture or infused in vivo within $1 \mathrm{~h}$.

Mixed lymphocyte cultures. Irradiated (1,500 cGy) stimulator cells $\left(2.5 \times 10^{6} / \mathrm{ml}\right)$ were cultured with responder cells $\left(2 \times 10^{6} / \mathrm{ml}\right)$ in microtiter plates with flat-bottomed wells in $0.2 \mathrm{ml}$ of culture medium for $4 \mathrm{~d}$ before assay of $\left[{ }^{3} \mathrm{H}\right]$ thymidine incorporation. For generation of CTL, identical ratios of responder and stimulator cells were cultured for $5 \mathrm{~d}$ in upright $25-\mathrm{cm}^{2}$ tissue culture flasks in $6 \mathrm{ml}$ of culture medium. In some experiments, cultures were supplemented with $10 \%$ rat Con A supernatant.

Cell-mediated cytotoxicity assays. Splenic blast cells were induced by a 2-d incubation with lipopolysaccharide (LPS, $50 \mu \mathrm{g} / \mathrm{ml}$; Escherichia coli 027:B8, Difco Laboratories, Inc., Detroit, MI) and dextran sulfate $(20 \mu \mathrm{g} / \mathrm{ml}$, mean mol wt 500,000 , Sigma Chemical Co.) in culture medium supplemented with $10 \%$ FBS. Alloantigen-specific killing against stimulator lymphoblasts was assessed in 4-h ${ }^{51} \mathrm{Cr}$ release assays, and the percentage of specific lysis was calculated as described (30).

Transplantation. Recipients were maintained on acidified ( $\mathrm{pH} 2)$, antibiotic (neomycin, $100 \mathrm{mg} /$ liter, and polymyxin $\mathrm{B}, 10 \mathrm{mg} / \mathrm{liter}$ ) $\mathrm{H}_{2} \mathrm{O}$ for 2-3 d before and $7 \mathrm{~d}$ after transplantation. On the day of transplantation, recipients were irradiated (900 cGy) and 2-6 h later were injected via the lateral tail vein with donor cells in $0.5 \mathrm{ml}$ of HBSS.

Histologic evaluation of gastrointestinal GVHD. Mice were killed and the viscera were removed intact and fixed in 10\% Carson's formalin. From each mouse, six sections of colon (two from cecum, two from transverse colon, and two from descending colon) were paraffin embedded and 4-5- $\mu \mathrm{m}$ sections were stained with hematoxylin and eosin for examination by light microscopy. Because of loss in processing, only four or five colon sections were available in four of the 36 mice examined. Microscopic sections were examined in a blinded fashion by the same observer (Dr. M. Eigenbrodt) and severity of seven distinct histologic features was graded. These seven features of GVHD were $(a)$ mononuclear leukocyte infiltration of the mucosa and submucosa, $(b)$ polymorphonuclear leukocyte infiltration of the mucosa and submucosa, $(c)$ mononuclear leukocyte infiltration of the mesenteric fat and blood vessels, $(d)$ polymorphonuclear leukocyte infiltration of the mesenteric fat and blood vessels, $(e)$ increased epithelial cell proliferation in the crypts of Lieberkuhn, $(f)$ increased mucosal surface epithelial proliferation, and $(g)$ loss of goblet cells.

Mononuclear cell and granulocytic inflammatory infiltrates were graded on a scale from 0 (no increased inflammatory cells) to $3+$ (marked infiltration with inflammatory cells). Nuclear crowding in intestinal crypt and surface epithelium and surface proliferative changes were separately evaluated as markers of the increased rate of intestinal epithelial cell proliferation which is induced by GVHD. Nuclear crowding varied from normal epithelium $(0+)$ to $3+$ changes in which epithelial cells in the outer one-third of the crypts contained large hyperchromatic nuclei with pseudostratification which imparted an adenomatous appearance. Surface proliferations varied from normal surface architecture $(0+)$ to changes associated with extensive piling up of cells to form papillary structures $(3+)$. Loss of goblet cells was evaluated with abnormalities varying from no loss of goblet cells $(0+)$ to total absence of goblet cells $(3+)$.

Other features that were sometimes observed included increased gut wall thickness and edema, crypt abscesses, lymphatic dilatation, lymphatic cellular collections or thrombi, and blebs formed by separation of the surface epithelium from the underlying lamina propria. These features were frequently focal and were not scored or grouped with the various diffuse histologic abnormalities in calculation of an overall severity score. When severity scores of the cecum, the transverse colon and the descending colon were compared, no statistically significant differences (Newman-Keuls multiple comparison procedure) in severity of any category of histologic lesion were noted. Therefore, the severity of each histologic lesion in individual mice is reported as the means of the scores recorded for the sections obtained from these three areas of the colon.

In vivo CTL generation. To assess in vivo CTL generation, $15 \times 10^{6}$ responder spleen cells were infused via lateral tail vein into irradiated ( $900 \mathrm{cGy}$ ) B6D2F1 mice. At varying time points after transplantation, recipient mice were killed and spleen cells were harvested, suspended 
in culture medium with $10 \%$ Con A-stimulated rat $\mathrm{SpC}$ supernatant, and cultured overnight in $25-\mathrm{cm}^{2}$ culture flasks before assessment of cell-mediated cytotoxicity.

\section{Results}

$D B A / 2$ and $B 6$ parental spleen and bone marrow cells differ in the capacity to induce lethal GVHD in irradiated B6D2F1 recipients. In previous studies, it was noted that incubation of B6 $\left(\mathrm{H}-2^{\mathrm{b}}\right)$ bone marrow and spleen cells with $250 \mu \mathrm{M}$ LeuLeu-OMe before transfer to irradiated B6D2F1 $\left(\mathrm{H}-2^{\mathrm{b}, \mathrm{d}}\right)$ recipients prevented lethal GVHD and permitted establishment of long-lived immunocompetent chimeras $(17,18,31)$. Thus, as demonstrated in the experiment depicted in the left panel of Fig. 1, when $10^{7} \mathrm{~B} 6 \mathrm{SpC}$ were infused into irradiated B6D2F1 recipients, uniformly lethal GVHD was observed. However, when the B6 donor cell inoculum was preincubated with LeuLeu-OMe before infusion into lethally irradiated B6D2F1 recipients, uniform long-term survival was noted.

When experiments were carried out to assess the course of GVHD induced by transfer of control and Leu-Leu-OMetreated $\mathrm{DBA} / 2$ parental donor cells to irradiated $\mathrm{B} 6 \mathrm{D} 2 \mathrm{~F} 1$ recipients, a different pattern of GVHD was observed. As demonstrated by the experiments depicted in the right panel of Fig. 1 , infusion of $20 \times 10^{6}\left(10 \times 10^{6} \mathrm{BMC}+10 \times 10^{6} \mathrm{SpC}\right)$ or 60 $\times 10^{6}\left(10 \times 10^{6} \mathrm{BMC}+50 \times 10^{6} \mathrm{SpC}\right)$ control or Leu-LeuOMe-treated DBA/2 donor cells into irradiated B6D2F1 recipients was associated with uniform long-term survival. However, during the first 2 mo after transfer of DBA/2 BMC and $\mathrm{SpC}, \mathrm{DBA} / 2 \rightarrow \mathrm{B} 6 \mathrm{D} 2 \mathrm{~F} 1$ mice developed diarrhea. As illustrated in Fig. 2, $A-C$, irradiated $\mathrm{B} 6 \mathrm{D} 2 \mathrm{~F} 1$ recipients of control (Fig. $2 A$ ) or Leu-Leu-OMe-treated (Fig. $2 B$ ) DBA/2 BMC and $\mathrm{SpC}$ were found to have extensive colonic inflammatory lesions. Histologic abnormalities in the colons of these mice were characterized by lymphocytic infiltration of the lamina propria, submucosa and mesenteric fat with dilatation of vessels in the submucosa and muscularis propria, thinning of the muscularis propria, and loss of mucosal goblet cells. Areas of

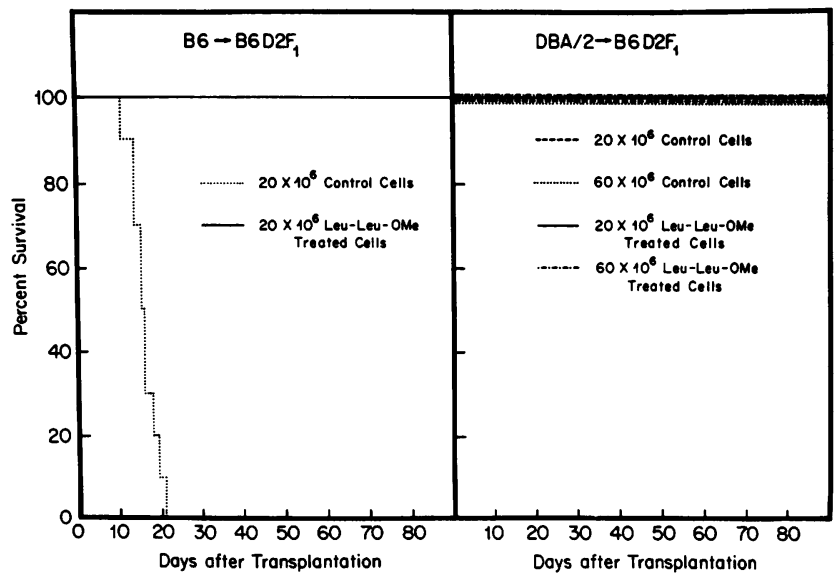

Figure 1. Lethal GVHD develops in B6D2F1 recipients of B6 but not $\mathrm{DBA} / 2$ parental donor cells. After irradiation, $\mathrm{B} 6 \mathrm{D} 2 \mathrm{~F} 1$ mice received $20 \times 10^{6}\left(10 \times 10^{6}\right.$ bone marrow cells $\left.+10 \times 10^{6} \mathrm{SpC}\right)$ or 60 $\times 10^{6}\left(10 \times 10^{6}\right.$ bone marrow cells $\left.+50 \times 10^{6} \mathrm{SpC}\right)$ control or LeuLeu-OMe-treated cells from the indicated parental donor strains. All survival curves represent groups of 10 animals except that data are shown for five recipients of $60 \times 10^{6}$ control or Leu-Leu-OMetreated DBA/2 SpC. granulocytic infiltration of the lamina propria and crypt abscesses were also noted. Such lesions were present throughout the colon and rectum of DBA/2 $\rightarrow \mathrm{B} 6 \mathrm{D} 2 \mathrm{~F} 1$ mice, whereas the histology of the stomach, duodenum, jejunum, and ileum in such mice displayed minimal inflammatory changes (data not shown). Periportal inflammatory changes were present in the livers of B6D2F1 recipients of control or Leu-Leu-OMetreated DBA/2 cells but the heart, lungs, kidneys, and skin of these animals were essentially normal on histologic examination. Whereas the histologic pattern of intestinal injury seen in B6D2F1 recipients of control or Leu-Leu-OMe-treated $\mathrm{DBA} / 2 \mathrm{BMC}+\mathrm{SpC}$ was not discernibly different, such lesions were absent in similarly irradiated and housed $\mathrm{B} 6 \mathrm{D} 2 \mathrm{~F} 1$ recipients of Thy 1.2 + C-treated DBA/2 BMC and SpC, as illustrated in Fig. $2 C$.

In vitro responses of $B 6$ or $D B A / 2$ spleen cells to $B 6 D 2 F 1$ stimulator cells are not differentially affected by Leu-Leu-OMe treatment. The experiments detailed in Tables I and II were designed to examine the possibility that strain differences in $\mathrm{SpC}$ sensitivity to the effects of Leu-Leu-OMe might in part explain the fact that Leu-Leu-OMe treatment of donor cells had no apparent effect on the course of GVHD in DBA/ $2 \rightarrow$ B6D2F1 mice. As shown by the results of the experiments contained in Table I, Leu-Leu-OMe treatment of B6 or DBA/2 spleen cells results in a reduction of subsequent proliferative responses to irradiated $\mathrm{B} 6 \mathrm{D} 2 \mathrm{~F} 1$ allogeneic spleen cells. The alloproliferative capacity of both Lyt2(-) DBA/2 SpC and Lyt2(-) B6 SpC was more highly conserved after Leu-LeuOMe treatment than were the responses of whole spleen cell populations. These findings indicated that as previously demonstrated for B6 spleen cells, alloproliferative responses of DBA/2 L3T4(+) spleen T cells are largely preserved after LeuLeu-OMe treatment.

In additional studies, the effects of Leu-Leu-OMe treatment on allocytotoxic responses of DBA/2 and $\mathrm{B} 6 \mathrm{SpC}$ were examined (Table II). As demonstrated by the results of experiments 1 and 2, Leu-Leu-OMe treatment of B6 or DBA/2 SpC abolished the capacity to generate B6D2F1-specific CTL in mixed lymphocyte cultures. Experiments 3 and 4 in Table II were designed to examine the effects of Leu-Leu-OMe treatment on generation of CTL from L3T4(+) T cells. Because L3T4(+) CTL generation is best demonstrated after culture of Lyt2(-) responder cells in mixed lymphocyte cultures supplemented with $\mathrm{T}$ cell lymphokines (32), Con A-stimulated rat $\mathrm{SpC}$ supernatants $(10 \%, \mathrm{vol} / \mathrm{vol})$ were added to these cultures. As can be seen in experiments 3 and 4 in Table II, CTL could be generated from both unseparated $\mathrm{SpC}$ and Lyt2 depleted $\mathrm{SpC}$. Generation of CTL from each population was prevented by treatment with Leu-Leu-OMe. The CTL generated from Lyt2 depleted SpC were resistant to anti-Lyt2 + C treatment (Table II) but were inhibited by addition of anti-L3T4 MAb to cytotoxicity assays (data not shown). Leu-Leu-OMe treatment eliminated both Lyt2(+) and L3T4(+) pre-CTL from DBA/2 and $\mathrm{B} 6 \mathrm{SpC}$ comparably.

Capacity to generate anti-host CTL in vivo is ablated by Leu-Leu-OMe treatment of $B 6$ and DBA/2 splenic $T$ cells. The in vitro assays of alloantigen-induced immune responses detailed in Tables I and II demonstrated no differences between B6 and DBA/2 spleen cells with regard to sensitivity to LeuLeu-OMe treatment. However, the marked disparity between the manifestations of GVHD generated in irradiated B6D2F1 recipients of $\mathrm{B} 6 \mathrm{vs}$. DBA/2 splenic $\mathrm{T}$ cells suggested that the in 

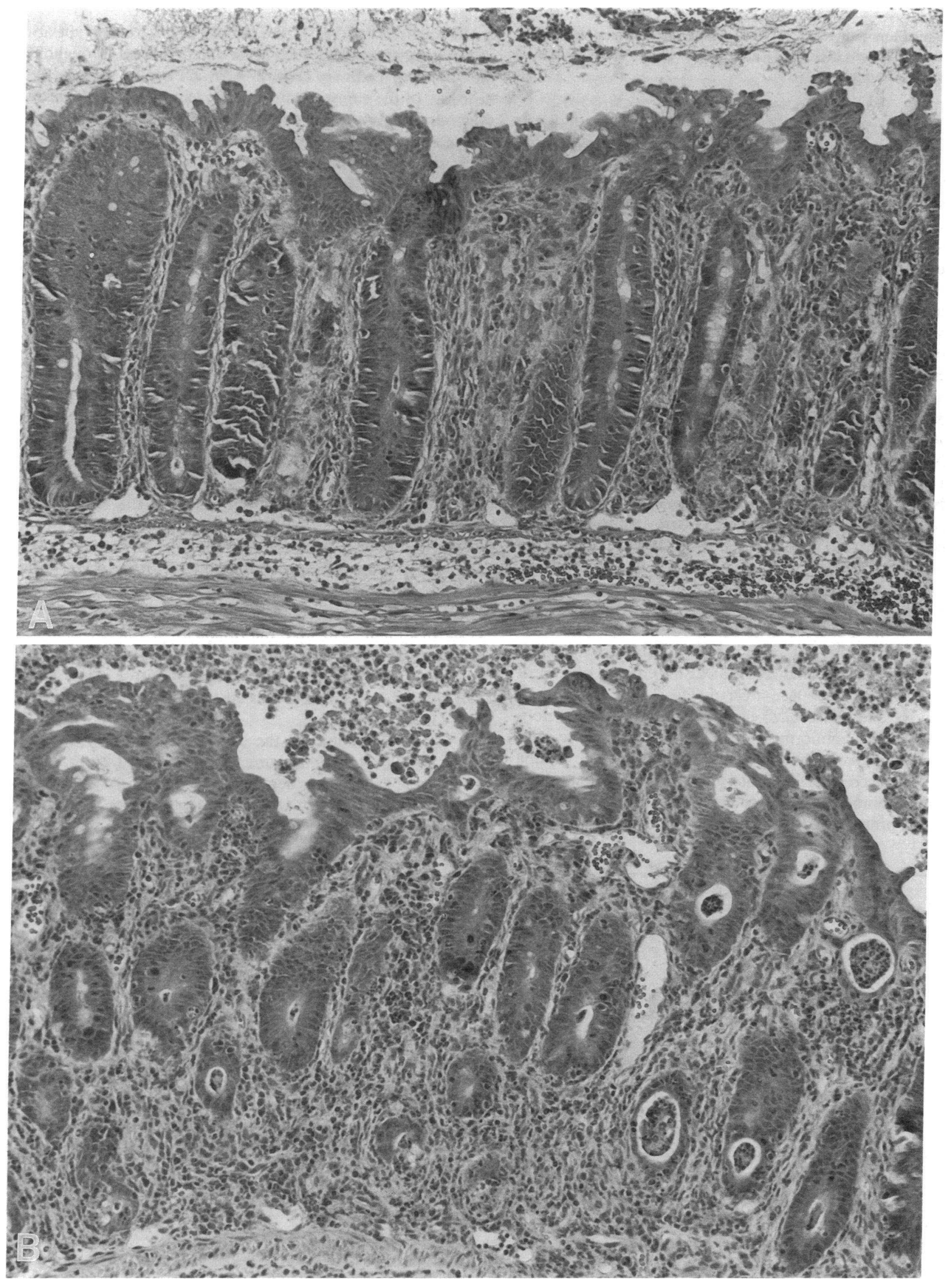

Figure 2 . 


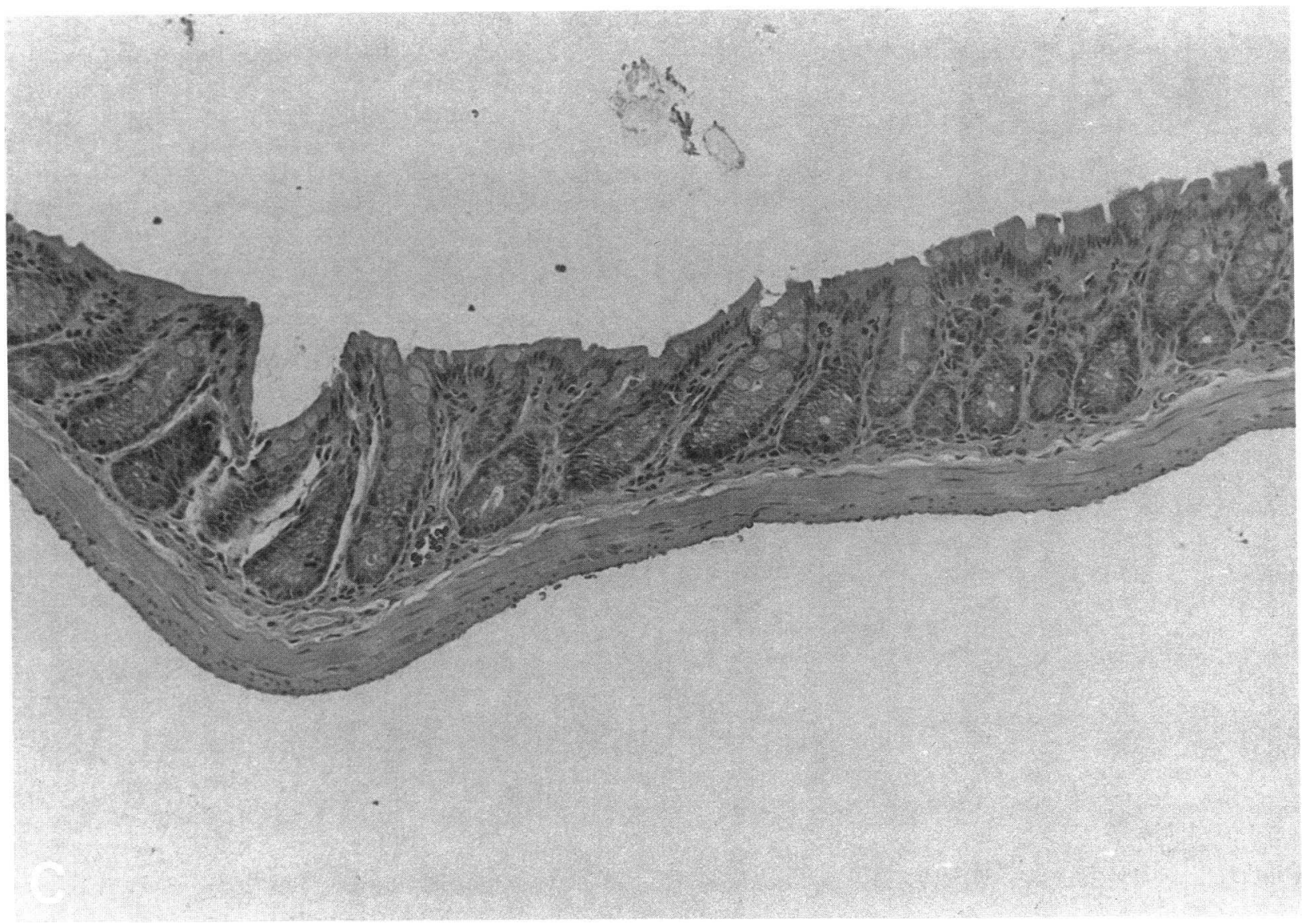

Figure 2. Histologic appearance of colons from DBA/2 $\rightarrow$ B6D2F1 mice. Irradiated B6D2F1 mice were killed $25 \mathrm{~d}$ after transfer of control $(A)$, Leu-Leu-OMe-treated $(B)$, or anti-Thy $1.2+\mathrm{C}$-treated $(C)$ DBA/2 donor bone marrow $\left(5 \times 10^{6}\right)$ and SpC $\left(5 \times 10^{6}\right)$. $($ Opposite $)$ Photomicrographs $A$ and $B$ demonstrate many of the similar histologic features manifested in these two groups of DBA/2 $\rightarrow$ B6D2F1 mice including diffuse neutrophilic and mononuclear cell infiltrates, loss of goblet cells, nuclear crowding in the crypts of Lieberkuhn and surface epithelial proliferative changes, edema of the submucosa, and crypt abscesses. Photomicrograph $C$ demonstrates the minimal numbers of colonic inflammatory cells and essential normal histology of the colons of B6D2F1 recipients of anti-Thy $1.2+\mathrm{C}$-treated DBA/2 donor cells.

vivo evolution of anti-B6D2F1 specific responses generated from each parental strain might be different. The experiments detailed in Table III were, therefore, designed to assess in vivo CTL generation after transfer of control or Leu-Leu-OMetreated donor SpC to irradiated B6D2F1 mice. To accomplish this, B6 or DBA/2 donor spleen cells were infused into irradiated B6D2F1 mice and recipient spleen cells were harvested at varying time intervals after transplantation. Cells capable of lysing $\mathrm{H}-2^{\mathrm{b}, \mathrm{d}}$-bearing B6D2F1 target cells could be detected in $\mathrm{SpC}$ obtained from irradiated $\mathrm{B} 6 \mathrm{D} 2 \mathrm{~F} 1$ recipients of control B6 or DBA/2 spleen cells. However, as previously reported (33), the ability to detect in vivo CTL generation was greatly enhanced without loss of specificity when $\mathrm{SpC}$ were cultured overnight in medium supplemented with $\mathrm{T}$ cell lymphokines before cytotoxicity assays. As demonstrated in Table III, antiB6D2F1-specific CTL were detected in SpC populations obtained from irradiated $\mathrm{B} 6 \mathrm{D} 2 \mathrm{~F} 1$ recipients of control $\mathrm{B} 6$ or DBA/2 donor cells. However, SpC obtained from B6D2F1 recipients of Leu-Leu-OMe-treated B6 or DBA/2 SpC manifested no anti-B6D2F1 cytotoxicity, regardless of when the mice were sacrificed after transplantation.

Colonic GVHD in $D B A / 2 \rightarrow B 6 D 2 F 1$ mice can be generated by transfer of Leu-Leu-OMe-resistant L3T4(+) T helper cells alone. As anti-B6D2F1-specific CTL could not be generated from Leu-Leu-OMe-treated DBA/2 SpC, the gastrointes- tinal GVHD developing in irradiated B6D2F1 recipients of Leu-Leu-OMe-treated DBA/2 spleen cells was likely to be generated by effector mechanisms distinct from classic $\mathrm{T}$ cell cytotoxicity. The studies detailed in Fig. 3 examined this possibility in greater detail. Pathologic changes were most apparent 2-5 wk after transplantation in the gastrointestinal tracts of B6D2F 1 recipients of control DBA/2 spleen cells. Therefore, animals were routinely killed for pathologic evaluation $25 \mathrm{~d}$ after transfer of $\mathrm{DBA} / 2$ donor cells. Irradiated $\mathrm{B} 6 \mathrm{D} 2 \mathrm{~F} 1$ recipients of anti-Thy 1.2 + C-treated DBA/ 2 bone marrow $\left(5 \times 10^{6}\right.$ cells) and $\mathrm{SpC}\left(5 \times 10^{6}\right)$ exhibited minimal if any abnormalities in the histologic categories assessed (group F, Fig. 3). In contrast, recipients of control DBA/2 bone marrow and $\mathrm{SpC}$ developed statistically significant degrees of abnormalities in each of the seven histologic categories (group A, Fig. 3). LeuLeu-OMe treatment of donor SpC before transfer to B6D2F1 recipient mice had no statistically significant effect on the severity of gastrointestinal GVHD lesions as determined either by assessment of individual pathologic parameters or by the total enteropathy score (group B, Fig. 3). When the capacity of T cell subsets to initiate GVHD was examined, it was noted that the overall severity of gastrointestinal GVHD generated by L3T4(+) donor T cells (group C) was significantly greater than that generated by Lyt2(+) donor T cells (group E), although each $T$ cell subset induced more severe pathologic 
Table I. Effect of Leu-Leu-OMe Preincubation on Alloantigeninduced Murine Spleen Cell DNA Synthesis: Partial Preservation of $B 6$ and DBA/2 T Cell-Proliferative Responses

\begin{tabular}{|c|c|c|c|c|c|}
\hline \multicolumn{3}{|c|}{ Responder spleen cells* } & \multicolumn{3}{|c|}{$\begin{array}{l}{\left[{ }^{3} \mathrm{H}\right] \text { Thymidine incorporation of }} \\
\text { responder cells cultured with } \\
\text { stimulator cells }{ }^{\ddagger}\end{array}$} \\
\hline \multirow[t]{2}{*}{ Strain } & \multirow[t]{2}{*}{$\mathrm{MAb}+\mathrm{C}$} & \multirow[t]{2}{*}{$\begin{array}{c}\text { Leu-Leu-OMe } \\
\text { treatment }\end{array}$} & B6 & $\mathrm{DBA} / 2$ & B6D2F1 \\
\hline & & & \multicolumn{3}{|c|}{$c p m \times 10^{-3}$} \\
\hline B6 & Nil & - & $22 \pm 11$ & - & $147 \pm 12$ \\
\hline B6 & Nil & + & $5 \pm 2$ & - & $72 \pm 16$ \\
\hline B6 & Anti-Lyt2 + C & - & $25 \pm 7$ & - & $128 \pm 2$ \\
\hline B6 & Anti-Lyt $2+C$ & + & $3 \pm 1$ & - & $92 \pm 2$ \\
\hline DBA/2 & Nil & - & - & $13 \pm 1$ & $84 \pm 7$ \\
\hline DBA $/ 2$ & Nil & + & - & $18 \pm 2$ & $59 \pm 1$ \\
\hline DBA $/ 2$ & Anti-Lyt2 + C & - & - & $13 \pm 3$ & $107 \pm 5$ \\
\hline $\mathrm{DBA} / 2$ & Anti-Lyt2 + C & + & - & $23 \pm 1$ & $96 \pm 7$ \\
\hline DBA/2 & Nil & - & - & $43 \pm 6$ & $211 \pm 9$ \\
\hline DBA $/ 2$ & Nil & + & - & $22 \pm 7$ & $145 \pm 18$ \\
\hline DBA $/ 2$ & Anti-Lyt2 + C & - & - & $52 \pm 8$ & $155 \pm 20$ \\
\hline $\mathrm{DBA} / 2$ & Anti-Lyt $2+C$ & + & - & $24 \pm 3$ & $120 \pm 14$ \\
\hline
\end{tabular}

All data are expressed as the mean \pm SEM of triplicate alloantigen-stimulated and autoantigen-stimulated cultures.

* Freshly isolated B6 or DBA/2 SpC were treated with anti-Lyt2, anti-Lyt2.2 $+\mathrm{C}$ or anti-Lyt2, anti-Lyt $2.1+\mathrm{C}$, respectively, as indicated, and then incubated for $15 \mathrm{~min}$ at room temperature in the presence or absence of $250 \mu \mathrm{M}$ Leu-Leu-OMe before mixed lymphocyte culture. ${ }^{\ddagger}$ Responder $\mathrm{SpC}$ were cultured with irradiated syngeneic or allogeneic (B6D2F1) SpC.

changes in the colon than anti-Thy $1.2+$ C-treated DBA/2 donor cells (group F, Fig. 3). Although the mean severity of colonic GVHD induced by L3T4(+) donor T cells (group C) was greater than that induced by Lyt $2(+) \mathrm{T}$ cells (group $\mathrm{E}$ ) in each of the histologic categories assessed, these differences achieved statistical significance only in assessment of the two aspects of mesenteric inflammation and in the total enteropathy scores. The lack of requirement for CTL responses in the development of gastrointestinal GVHD was confirmed by the observation that anti-Lyt $2+\mathrm{C}$ and Leu-Leu-OMe-treated DBA/ 2 donor SpC also caused colonic GVHD lesions in $\mathrm{B} 6 \mathrm{D} 2 \mathrm{~F} 1$ recipients (groups $\mathrm{C}$ and $\mathrm{D}$, respectively) that were not discernibly different from those seen in recipients of control DBA/2 SpC (group A). Of note, however, Leu-Leu-OMe treatment of L3T4(+) cells did result in a statistically significant decrease in the severity of mesenteric inflammation but not in other individual measures of severity or in the overall enteropathy score (group D vs. group C, Fig. 3).

The studies detailed in Fig. 3 suggested that either L3T4(+) or Lyt2(+) DBA/2 splenic $\mathrm{T}$ cells could induce intestinal GVHD in irradiated B6D2F1 recipients. However, inasmuch as these donor $\mathrm{T}$ cell subsets were isolated by MAb + C-mediated depletion of the reciprocal $\mathrm{T}$ cell subset, it remained possible that Thy1.2(+), L3T4(-), Lyt2(-) DBA/2 T cells were the critical donor $T$ cell population responsible for generating this enteropathic syndrome. The experiment detailed in Table IV was therefore performed. Again, transfer of control $\mathrm{DBA} / 2$ bone marrow and spleen cells to irradiated B6D2F1 recipients was associated with development of severe intestinal GVHD. However, either anti-Thy $1.2+\mathrm{C}$ or combined antiL3T4 and anti-Lyt $2+\mathrm{C}$ treatment of DBA/2 donor SpC was found to ablate the capacity to generate significant intestinal GVHD in B6D2F1 recipients. GVHD in this model cannot be accounted for by the activity of an L3T4(-), Lyt2(-) T cell but rather is caused by either $\mathrm{L} 3 \mathrm{~T} 4(+)$ or $\mathrm{Lyt} 2(+)$ effector T cells.

\section{Discussion}

Gastrointestinal involvement is a major cause of morbidity from human GVHD. In both human and murine models of GVHD, high mortality rates are frequently seen in association

Table II. Loss of Allospecific CTL Generation after Preincubation with Leu-Leu-OMe

\begin{tabular}{|c|c|c|c|c|c|c|c|}
\hline \multirow[b]{3}{*}{ Experiment } & \multirow{2}{*}{\multicolumn{3}{|c|}{ Responder spleen cells* }} & \multirow{3}{*}{$\begin{array}{l}\text { Supplemental } \\
\text { rat Con A } \\
\text { supernatant }\end{array}$} & \multicolumn{3}{|c|}{ Effector cells ${ }^{\ddagger}$} \\
\hline & & & & & \multicolumn{2}{|c|}{ Control } & \multirow{2}{*}{$\begin{array}{c}\text { Anti-Lyt2 + C } \\
\text { treatment } \\
80: 1\end{array}$} \\
\hline & Strain & $M A b+C$ & $\begin{array}{l}\text { Leu-Leu-OMe } \\
\text { treatment }\end{array}$ & & $20: 1$ & $80: 1$ & \\
\hline \multirow[t]{2}{*}{1} & B6 & Nil & - & - & 42 & 51 & $\mathrm{ND}^{\mathrm{c}}$ \\
\hline & B6 & Nil & + & - & 1 & 1 & ND \\
\hline \multirow[t]{2}{*}{2} & $\mathrm{DBA} / 2$ & Nil & - & - & 26 & 32 & ND \\
\hline & $\mathrm{DBA} / 2$ & Nil & + & - & 1 & -2 & ND \\
\hline \multirow[t]{3}{*}{3} & B6 & Nil & - & + & 47 & 55 & 3 \\
\hline & B6 & Anti-Lyt2 + C & - & + & 8 & 22 & 19 \\
\hline & B6 & Anti-Lyt2 + C & + & + & -3 & -3 & -1 \\
\hline \multirow[t]{3}{*}{4} & $\mathrm{DBA} / 2$ & Nil & - & + & 72 & 78 & 14 \\
\hline & $\mathrm{DBA} / 2$ & Anti-Lyt2 + C & - & + & 20 & 25 & 21 \\
\hline & $\mathrm{DBA} / 2$ & Anti-Lyt2 + C & + & + & -3 & -8 & -10 \\
\hline
\end{tabular}

Data shown are percentage specific lysis of B6D2F1 lymphoblasts at the indicated effector to target ratios (E/T). In experiment 3, < 5\% specific lysis of B6 lymphoblasts at an E/T ratio of 80:1 by all effector populations was noted, and in experiment 4, all effector cell populations caused $<4 \%$ specific lysis of $\mathrm{H}-2^{\mathrm{d}}$ (B10.D2) lymphoblasts at an E/T ratio of 80:1.

* Responder spleen cells were prepared as in Table I. ${ }^{\ddagger}$ After 5-d mixed lymphocyte cultures, effector cells were assayed immediately (experiments 1 and 2) for the capacity to lyse B6D2F1 lymphoblasts or were treated with complement alone or with anti-Lyt2, anti-Lyt2.2 and C (experiment 3) or anti-Lyt2, anti-Lyt2.1 and C (experiment 4) before assay of allospecific cytotoxicity. 
Table III. Treatment of Donor Spleen Cells with Leu-Leu-OMe Abolishes Allospecific CTL Generation In Vivo

\begin{tabular}{|c|c|c|c|c|}
\hline \multirow[b]{2}{*}{ Spleen cells } & \multirow[b]{2}{*}{ Treatment of donor $\mathrm{SpC}$} & \multirow{2}{*}{$\begin{array}{c}\text { Days after } \\
\text { transfer of } \mathrm{SpC} \\
\text { into irradiated } \\
\text { recipients* }\end{array}$} & \multicolumn{2}{|c|}{$\begin{array}{c}\text { Percent } \\
\text { specific } \\
\text { cytolysis of } \\
\text { B6D2F1 } \\
\text { blasts }\end{array}$} \\
\hline & & & $1: 10$ & $40: 1$ \\
\hline \multirow[t]{4}{*}{$\mathrm{B} 6 \rightarrow \mathrm{B} 6 \mathrm{D} 2 \mathrm{~F} 1$} & Nil & 5 & 49 & 65 \\
\hline & Leu-Leu-OMe & 5 & $<1$ & $<1$ \\
\hline & Nil & 10 & 26 & 45 \\
\hline & Leu-Leu-OMe & 10 & $<1$ & $<1$ \\
\hline \multirow[t]{6}{*}{$\mathrm{DBA} / 2 \rightarrow \mathrm{B} 6 \mathrm{D} 2 \mathrm{~F} 1$} & Nil & 4 & 31 & 31 \\
\hline & Leu-Leu-OMe & 4 & $<1$ & $<1$ \\
\hline & Nil & 5 & 28 & 40 \\
\hline & Leu-Leu-OMe & 5 & $<1$ & $<1$ \\
\hline & Nil & 6 & 29 & 49 \\
\hline & Leu-Leu-OMe & 6 & $<1$ & $<1$ \\
\hline \multirow[t]{6}{*}{$\mathrm{DBA} / 2 \rightarrow \mathrm{B} 6 \mathrm{D} 2 \mathrm{~F} 1$} & Nil & 5 & 69 & 78 \\
\hline & Leu-Leu-OMe & 5 & $<1$ & $<1$ \\
\hline & Nil & 7 & 37 & ND \\
\hline & Leu-Leu-OMe & 7 & $<1$ & $<1$ \\
\hline & Nil & 12 & 6 & 17 \\
\hline & Leu-Leu-OMe & 12 & $<1$ & $<1$ \\
\hline
\end{tabular}

$\mathrm{ND}$, not done. * DBA/2 or B6 donor SpC were preincubated in the presence or absence of $250 \mu \mathrm{M}$ Leu-Leu-OMe before infusion of 15 $\times 10^{6}$ donor $\mathrm{SpC}$ into irradiated B6D2F1 recipient mice. Chimeras were killed on the indicated days after transfer of donor SpC. Chimeric $\mathrm{SpC}$ were then incubated overnight in medium supplemented with $10 \%$ rat Con A supernatant (expt. 2) or 5\% EL4 supernatant (expts. 1 and 3) and assayed the next day for lysis of host ${ }^{51} \mathrm{Cr}$-labeled LPS blasts. " Lysis of DBA/2 LPS blasts by spleen cells obtained from DBA/2 $\rightarrow$ B6D2F1 mice or of B6 LPS blasts by spleen cells obtained from $\mathrm{B} 6 \rightarrow \mathrm{B} 6 \mathrm{D} 2 \mathrm{~F} 1$ mice was $<2 \%$.

with more severe forms of gut GVHD. A striking feature of the current studies, however, is the disparity between mortality and severe gastrointestinal involvement as well as the manner in which these two manifestations of GVHD are modulated by Leu-Leu-OMe treatment of donor cells. Thus, DBA/ 2 donor T cells generate severe colonic GVHD in irradiated B6D2F1 recipients, but lethal disease did not develop in this strain combination. Furthermore, Leu-Leu-OMe treatment of donor cells had no significant effect on the severity of the tissue damage generated in the colons of $\mathrm{B} 6 \mathrm{D} 2 \mathrm{~F} 1$ recipients of $\mathrm{DBA} / 2$ donor $\mathrm{T}$ cells. In contrast, similar treatment of $\mathrm{B} 6$ donor $\mathrm{T}$ cells consistently prevented the development of lethal GVHD (18). Because Leu-Leu-OMe treatment of DBA/2 or B6 SpC was similarly effective in preventing in vitro or in vivo generation of B6D2F1-specific CTL, these findings indicate that $\mathrm{T}$ cellmediated cytotoxicity does not play an essential role in the cascade of donor anti-host immune responses that generate gastrointestinal GVHD.

In contrast to the $\mathrm{B} 6 \rightarrow \mathrm{B} 6 \mathrm{D} 2 \mathrm{~F} 1$ and many other parent $\rightarrow$ $\mathrm{F} 1$ strain combinations, transfer of control DBA/2 donor $\mathrm{SpC}$ and bone marrow to lethally irradiated $B 6 D 2 F 1$ recipients does not generate lethal GVHD despite the presence of class I and II MHC and multiple non-MHC encoded histocompatibility antigen differences. Rolink and Gleichmann as well as other groups of investigators have noted the dichotomy between the acutely lethal "allosuppressive" GVHD induced by $\mathrm{B} 10$ or B6 donor cells, and the relatively less lethal "lymphoproliferative" GVHD induced by DBA/2 donor cells in nonirradiated $F 1$ recipients $(20,22,23)$. In contrast to the systemic lupus erythematosus-like syndrome noted after transfer of DBA/ 2 donor cells to nonirradiated B6D2F1 donors, we have found no evidence for immune-complex nephritis in lethally irradiated $F 1$ recipients of DBA/ 2 donor cells (data not shown). However, DBA/2 $\rightarrow$ B6D2F1 mice developed a diarrheal syndrome that was equal to, if not greater in severity, than that observed in other parent $\rightarrow F 1$ strain combinations, such as $\mathrm{B} 10 \mathrm{D} 2 \rightarrow \mathrm{B} 6 \mathrm{D} 2 \mathrm{~F} 1$ or $\mathrm{CBA} \rightarrow \mathrm{B} 6 \mathrm{xCBAF} 1$. In these latter strains, mortality was commonly observed when the recipients received control and not Leu-Leu-OMe-treated donor cells, whereas diarrhea was observed when animals received Leu-Leu-OMe-treated cells (data not shown). The fact that long-term survival was uniformly observed in these mice despite development of severe transmural intestinal GVHD suggests that other aspects of GVHD such as the profound immunosuppression reported to be present in B6 $\rightarrow$ B6D2F1 GVHD mice but not in DBA/2 $\rightarrow$ B6D2F1 mice (20-22) or B6D2F1 recipients of Leu-Leu-OMe treated B6 donor cells (31) might be a far more important determinant of overall mortality rates. Indeed, even in the B6 $\rightarrow$ B6D2F1 strain combination in which recipients of Leu-Leu-OMe-treated donor cells consistently fail to exhibit clinically apparent wasting or diarrhea $(17,18,31)$, histologic evaluation 4 wk after transplantation has also demonstrated extensive colonic inflammatory changes (data not shown). Since the early mortality observed in many strain combinations prevents detailed chronologic evaluation of enteropathic GVHD, the uniformly prolonged survival of $\mathrm{B} 6 \mathrm{D} 2 \mathrm{~F} 1$ recipients of $\mathrm{DBA} / 2$ donor $\mathrm{T}$ cells afforded an opportunity to examine in detail the features of intestinal GVHD generated by various donor $T$ cell populations.

It has been clearly demonstrated that introduction of mature $\mathrm{T}$ cells into an allogeneic host is essential for the generation of the mortality and organ-specific tissue injury associated with the syndrome of acute GVHD. However, the individual role of various $T$ cell subsets and their functional activities has been more difficult to delineate. The nature of intestinal GVHD generated in strain combinations with isolated class I MHC or class II MHC or in class I + II MHC disparate recipients of L3T4(+) and Lyt2(+) donor T cells has led other investigators to suggest that $\mathrm{L} 3 \mathrm{~T} 4(+)$ donor $\mathrm{T}$ cells responding to host class II MHC encoded histocompatibility antigen play a major role in generating such lesions $(10,34,35)$. The recent demonstration that treatment of GVHD mice with antibody to tumor necrosis factor greatly reduced both mortality and the severity of intestinal GVHD (36) has suggested that the role of donor $T$ cells in generating the gut lesions of GVHD may be mediated largely through alloantigen-stimulated induction of cytokine release. As $\mathrm{T}$ cells removed from the spleens or intestines of mice undergoing GVHD induced by isolated class II MHC disparities or by Lyt2(-) donor T cells have been found to contain little or no anti-host CTL activity when assessed immediately after isolation $(10,34)$, it has been suggested that CTL may play little or no role in the GVHD lesions generated by L3T4(+) donor T cells responding to host class II MHC encoded antigenic differences. However, we and other investigators have noted that in vivo activation of class II 

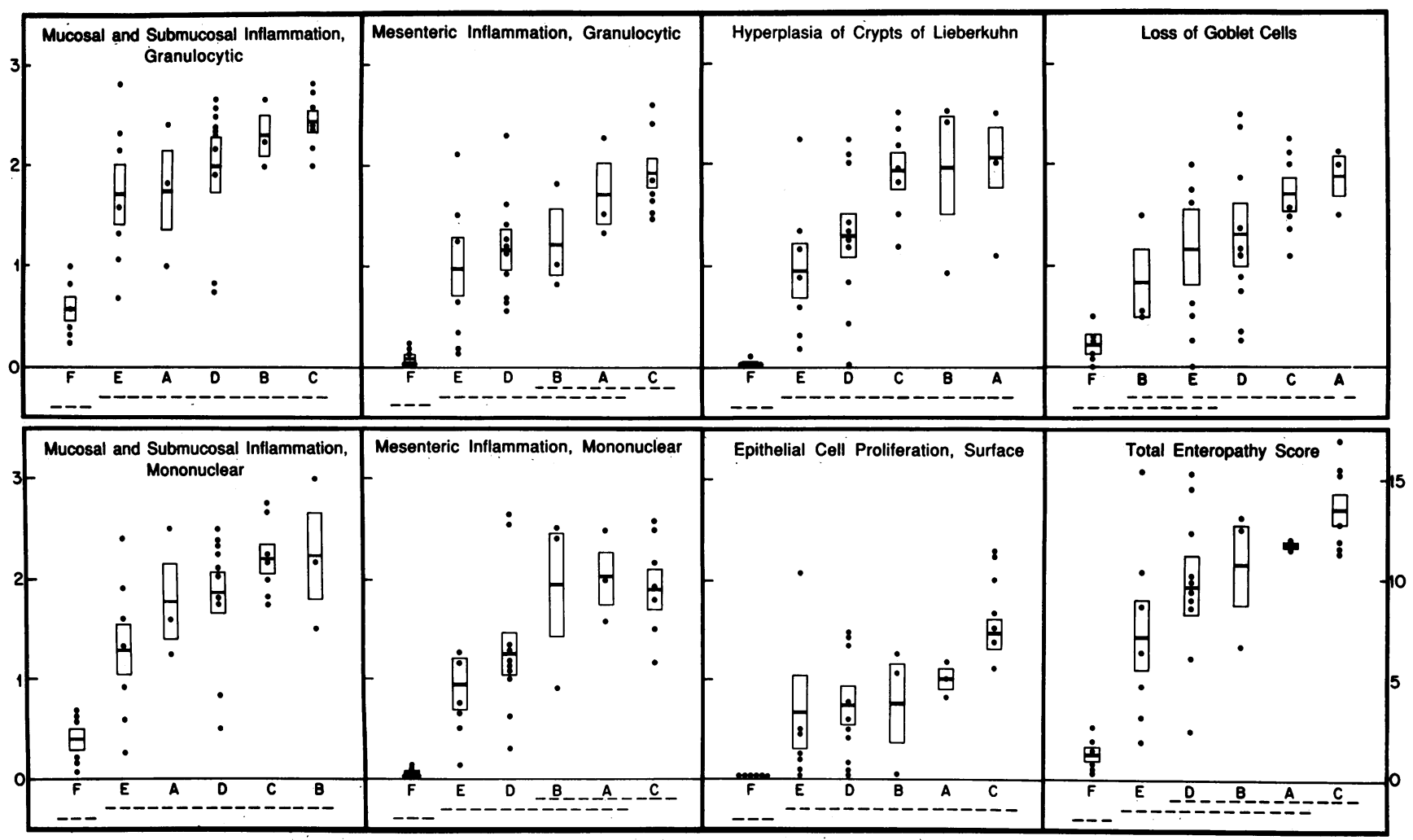

Figure 3. Severity of intestinal GVHD induced by various subsets of DBA/2 donor $T$ cells. Irradiated B6D2F1 mice were infused with $5 \times 10^{6}$ Thy $1.2+\mathrm{C}$-treated DBA/2 bone marrow cells and $5 \times 10^{6} \mathrm{DBA} / 2 \mathrm{SpC}$-treated as indicated in the key. Mice were killed $25 \mathrm{~d}$ after transplantation and histologic sections of the colon were prepared and assessed as detailed in the methods section. Each data point represents the mean histologic score in the indicated category of GVHD pathology for all colon sections examined in a single mouse. The overall mean histologic score \pm SE of the mean for all animals in each group is shown as a horizontal bar enclosed by a standard error box. The results were analyzed by the Newman-Keuls multiple comparison procedure, and the results of this statistical analysis are displayed graphically below each data chart. Any two means underscored by the same dashed line are not significantly different.

MHC antigen-specific CTL can be demonstrated in populations of $\mathrm{T}$ cells removed from spleens and/or intestines of mice undergoing GVHD $(10,33)$. Thus, a role for donor anti-host CTL in the development of various aspects of enteropathic GVHD cannot be excluded by studies relying solely on use of

Table IV. L3T4(-), Lyt2(-) DBA/2 Donor T Cells Are Not Responsible for Generation of Intestinal GVHD in Irradiated B6D2F1 Recipients

\begin{tabular}{clc}
\hline Mouse & \multicolumn{1}{c}{$\begin{array}{c}\text { Treatment of DBA/2 } \\
\text { SpC Cells }\end{array}$} & $\begin{array}{c}\text { Total enteropathy } \\
\text { score }^{*}\end{array}$ \\
\hline 1 & $\mathrm{C}$ & 14.0 \\
2 & $\mathrm{C}$ & 16.0 \\
3 & $\alpha \mathrm{L} 3 \mathrm{~T} 4, \alpha \mathrm{Lyt} 2+\mathrm{C}$ & 0.9 \\
4 & $\alpha \mathrm{L} 3 \mathrm{~T} 4, \alpha \mathrm{Lyt} 2+\mathrm{C}$ & 0.4 \\
5 & $\alpha$ Thy1 $1.2+\mathrm{C}$ & 0.2 \\
6 & $\alpha$ Thy1 $1.2+\mathrm{C}$ & 0.8 \\
\hline
\end{tabular}

* Each irradiated B6D2F1 recipient mouse received $5 \times 10^{6} \alpha$ Thy 1.2 $+\mathrm{C}$ and Leu-Leu-OMe-treated DBA/2 bone marrow cells and 5 $\times 10^{6} \mathrm{DBA} / 2 \mathrm{SpC}$ that had been treated as indicated.

₹ Total enteropathy score for each mouse was calculated as detailed in Fig. 3. donor/recipient strain combinations with limited histocompatibility antigen disparities or L3T4(+) vs. Lyt2(+) donor T cells.

The experiments described in this communication utilized an alternative approach to delineate the role of $\mathrm{T}$ cell cytotoxicity in the generation of GVHD tissue damage. Previous studies in our laboratory have demonstrated that exposure of human or murine lymphocytes to Leu-Leu-OMe results in the selective depletion of NK cells and the precursors of both CD4(+) and CD8(+) CTL, whereas B cells and a variety of T helper functions are relatively preserved. In a number of semiallogeneic class I + II MHC and multiple non-MHC encoded histocompatibility antigen disparate murine strain combinations, removal of donor anti-host CTL precursors by LeuLeu-OMe treatment has been shown to prevent lethal GVHD $(18,33)$ and thus has indicated that anti-host cytotoxicity plays an essential role in this syndrome. Of note, because depletion of neither CD4(+) nor CD8(+) $T$ cell subsets from the donor cell inoculum consistently prevents lethal GVHD in such strain combinations $(11,18)$, these results suggest that the efficiency of Leu-Leu-OMe treatment regimens in the prevention of lethal GVHD relates to the capacity to prevent both CD4(+) and CD8(+) anti-host CTL generation.

When the roles of various donor $\mathrm{T}$ cell populations in the 
generation of intestinal GVHD were examined in the current studies, it was noted that either donor Lyt2(-) or L3T4(-) T cell subsets, but not Lyt2(-), L3T4(-) T cells, can induce tissue pathology in class I + II MHC and multiple non-MHC histocompatibility antigen disparate recipients. In agreement with previous investigators it was also noted that comparable numbers of L3T4(+) T cell-enriched donor cells generate significantly more severe histologic changes than did Lyt2(+) donor $\mathrm{T}$ cells. The nature of the $\mathrm{T}$ cell functions necessary to initiate intestinal GVHD was further defined by the observation that development of gut GVHD was not prevented by Leu-Leu-OMe treatment of either unseparated or L3T4(+) T cell enriched, Lyt2(-) donor SpC. The dichotomy between the salutary effect of Leu-Leu-OMe treatment of B6 donor cells on mortality rates in $\mathrm{B} 6 \rightarrow \mathrm{B} 6 \mathrm{D} 2 \mathrm{~F} 1$ mice vs. the lack of effect of Leu-Leu-OMe treatment of DBA/2 donor cells on the subsequent generation of intestinal GVHD in the same recipient mice could not be explained by a disparity in the effects of Leu-Leu-OMe on B6 vs. DBA/2 CTL precursors. Thus, after Leu-Leu-OMe treatment of B6 or DBA/2 SpC, a similar loss of in vitro or in vivo CTL generation was observed. Furthermore, in both strains, the capacity for CTL generation from L3T4(+) $\mathrm{T}$ cells appeared to be ablated after Leu-Leu-OMe treatment. Thus, the current findings indicate no requisite role for donor anti-host CTL generation in the initiation of intestinal GVHD. Rather, GVHD enteropathy appears to be mediated by noncytotoxic donor anti-host $\mathrm{T}$ cell responses that are relatively preserved after Leu-Leu-OMe treatment.

It is not surprising that the submucosal edema and inflammatory infiltrates seen in intestinal GVHD are solely dependent on donor anti-host helper $\mathrm{T}$ cell responses. However, in the DBA/2 $\rightarrow$ B6D2F1 model of intestinal GVHD, a variety of destructive lesions are also generated as evidenced by the presence of crypt abscesses, goblet cell loss, and increased epithelial cell turnover. The fact that each of these lesions was readily apparent in $\mathrm{B} 6 \mathrm{D} 2 \mathrm{~F} 1$ recipients of $\mathrm{CTL}$ depleted DBA/2 donor cells indicates that such lesions can also be initiated by donor helper $\mathrm{T}$ cells. Presumably, these manifestations of gut GVHD are initiated by the lymphokine response of such alloreactive donor $\mathrm{T}$ cells. Whether such intestinal epithelial cell damage is mediated by the direct effect of $T$ cell products such as tumor necrosis factor (35), or indirectly through the activation of $\mathrm{NK}$, macrophages, or PMN, remains to be delineated.

In summary, our studies have used the DBA/2 $\rightarrow$ B6D2F1 murine model of bone marrow transplantation and GVHD to examine the nature of donor $\mathrm{T}$ functions which are required to generate GVHD enteropathy. The results indicate that a broad spectrum of intestinal histologic abnormalities are generated by donor anti-host $T$ cell responses distinct from cell-mediated cytotoxicity. Furthermore, the dichotomy between the prolonged long-term survival of DBA/2 $\rightarrow$ B6D2F1 mice and the severity of colonic GVHD lesions generated in these animals suggests that other aspects of GVHD may be more important in determining mortality.

\section{Acknowledgments}

The authors wish to thank R. Todd Parkey for excellent technical assistance and Mrs. Renate Davis for skillful preparation of the manuscript.
This work was supported by National Institutes of Health grant AI-24639. Dr. Bryde is the recipient of National Institutes of Health Postdoctoral Fellowship support from Cancer Immunology Training grant CA-09082.

\section{References}

1. Elkins, W. L. 1971. Cellular immunology and the pathogenesis of graft versus host reaction. Prog. Allergy. 15:78-187.

2. Korngold, R., and J. Sprent. 1978. Lethal graft-versus-host disease after bone marrow transplantation across minor histocompatibility barriers in mice: prevention by removing mature $T$ cells from marrow. J. Exp. Med. 48:1687-1698.

3. Vallera, D. A., C. C. B. Soderling, G. J. Carlson, and J. H. Kersey. 1981. Bone marrow transplantation across major histocompatibility barriers in mice: effect of elimination of $\mathrm{T}$ cells from donor grafts by treatment with monoclonal Thy-1.2 plus complement or antibody alone. Transplantation (Baltimore). 31:218-222.

4. Martin, P. J., J. A. Hansen, C. D. Buckner, J. E. Sanders, H. J. Deeg, P. Stewart, F. R. Appelbaum, R. Clift, A. Fefer, R. P. Witherspoon, M. S. Kennedy, K. M. Sullivan, N. Flournoy, R. Storb, and E. D. Thomas. 1985. Effects of in vitro depletion of T cells in HLAidentical allogeneic marrow grafts. Blood. 66:664-672.

5. Mitsuyasu, R. T., R. E. Champlin, R. P. Gale, W. G. Ho, C. Lenarsky, D. Winston, M. Selch, R. Elashoff, J. V. Giorgi, J. Wells, P. Terasaki, R. Billing, and S. Feig. 1986. Treatment of donor bone marrow with monoclonal anti-T-cell antibody and complement for the prevention of graft-versus host disease. Ann. Intern. Med. 105:2026.

6. Rappaport, H., A. Khalil, O. Halle-Pannenko, L. Pritchard, D. Dantchev, and G. Mathé. 1979. Histopathologic sequence of events in adult mice undergoing lethal graft-versus-host reaction developed across $\mathrm{H}-2$ and/or non-H-2 histocompatibility barriers. Am. J. Pathol. 96:121-142.

7. Thomas, E. D., R. Storb, R. A. Clift, A. Fefer, F. L. Johnson, P. E. Neiman, K. G. Lerner, H. Glucksberg, and C. D. Buckner. 1975. Bone-marrow transplantation. N. Engl. J. Med. 292:895-902.

8. Korngold, R., and J. Sprent. 1987. T cell subsets and graftversus-host disease. Transplantation (Baltimore). 44:335-339.

9. Korngold, R., and J. Sprent. 1983. Lethal GVHD across minor histocompatibility barriers: nature of the effector cells and role of the H-2 complex. Immunol. Rev. 71:5-28.

10. Piguet, P.-F. 1985. GVHR elicited by products of class I or class II loci of the MHC: Analysis of the response of mouse T lymphocytes to products of class I and class II loci of the MHC in correlation with GVHR-induced mortality, medullary aplasia, and enteropathy. J. Immunol. 135:1637-1643.

11. Korngold, R., and J. Sprent. 1985. Surface markers of T cells causing lethal graft-vs-host disease to class I vs class II H-2 differences. J. Immunol. 135:3004-3010.

12. von Boehmer, H., P. Kisielow, W. Leierson, and W. Haas 1984. Lyt- $2^{-}$cell-independent functions of $\mathrm{Lyt}-2^{+}$cells stimulated with antigen or concanavalin A. J. Immunol. 133:59-64.

13. Mizuochi, T., H. Golding, A. S. Rosenberg, L. H. Glimcher, T. R. Malek, and A. Singer. 1985. Both L3T4 ${ }^{+}$and $\mathrm{Lyt}_{-} 2^{+}$helper T cells initiate cytotoxic $\mathrm{T}$ lymphocyte responses against allogeneic major histocompatibility antigens but not against trinitrophenyl-modified self. J. Exp. Med. 162:427-443.

14. Golding, H., and A. Singer. 1985. Specificity, phenotype, and precursor frequency of primary cytolytic $\mathrm{T}$ lymphocytes specific for class II major histocompatibility antigens. J. Immunol. 135:16101615 .

15. Sprent, J., and M. Schaefer. 1985. Properties of purified T cell subsets. I. In vitro responses to class I vs. class II H-2 alloantigens. $J$. Exp. Med. 162:2068-2088.

16. Sprent, J., M. Schaefer, D. Lo, and R. Korngold. 1986. Properties of purified T cell subsets. II. In vivo responses to class I vs. class II H-2 differences. J. Exp. Med. 163:998-1011. 
17. Charley, M., D. L. Thiele, M. Bennett, and P. E. Lipsky. 1986. Prevention of lethal murine graft versus host disease by treatment of donor cells with L-leucyl-L-leucine methyl ester. J. Clin. Invest. 78:1415-1420.

18. Thiele, D. L., M. R. Charley, J. A. Calomeni, and P. E. Lipsky. 1987. Lethal graft-vs-host disease across major histocompatibility barriers: requirement for leucyl-leucine methyl ester sensitive cytotoxic $\mathrm{T}$ cells. J. Immunol. 138:51-57.

19. Thiele, D. L., and P. E. Lipsky. 1986. The immunosuppressive activity of L-leucyl-L-leucine methyl ester: selective ablation of cytotoxic lymphocytes and monocytes. J. Immunol. 136:1038-1048.

20. Rolink, A. G., and E. Gleichmann. 1983. Allosuppressor- and allohelper-T cells in acute and chronic graft-vs.-host (GVH) disease. III. Different Lyt subsets of donor T cells induce different pathological syndromes. J. Exp. Med. 158:546-558.

21. Pals, S. T., H. Gleichmann, and E. Gleichmann. 1984. Allosuppressor and allohelper $\mathrm{T}$ cells in acute and chronic graft-vs.-host disease. $V . F_{1}$ mice with secondary chronic $G V H D$ contain $F_{1}$-reactive allohelper but no allosuppressor T cells. J. Exp. Med. 159:508-523.

22. Gleichmann, E., S. T. Pals, A. G. Rolink, T. Radaszkiewicz, and H. Gleichmann. 1984. Graft-versus-host reactions: clues to the etiopathology of a spectrum of immunological diseases. Immunol. Today. 5:324-332.

23. Via, C. S., S. O. Sharrow, and G. M. Shearer. 1987. Role of cytotoxic $\mathrm{T}$ lymphocytes in the prevention of lupus-like disease occurring in a murine model of graft-vs-host disease. J. Immunol. 139:1840-1849.

24. Marshak-Rothstein, A., P. Fink, T. Gridley, D. H. Raulet, M. J. Bevan, and M. L. Gefter. 1979. Properties and applications of monoclonal antibodies directed against determinants of the Thy-1 locus. $J$. Immunol. 122:2491-2497.

25. Dialynas, D. P., D. B. Wilde, P. Marrack, A. Pierres, K. A. Wall, W. Havran, G. Otten, M. R. Loken, M. Pierres, J. Kappler, and F. W. Fitch. 1983. Characterization of the murine antigenic determinant, designated L3T4a, recognized by monoclonal antibody GK1.5: expression of L3T4a by functional T cell clones appears to correlate primarily with class II MHC antigen-reactivity. Immunol. Rev. 74:29_ 56.

26. Sarmiento, M., A. L. Glasebrook, and A. F. W. Fitch. 1980. IgG or IgM monoclonal antibodies reactive with different determinants of the molecular complex bearing Lyt 2 antigen block T cell-mediated cytolysis in the absence of complement. J. Immunol. 125:2665-2672.

27. Raulet, D. H., P. D. Gottlieb, and M. J. Bevan. 1980. Fractionation of lymphocyte populations with monoclonal antibodies specific for Lyt-2.2 and Lyt-3.1. J. Immunol. 125:1136-1143.

28. Hammerling G., U. Hammerling, and J. Kearney, editors. 1981. Monoclonal Antibodies and T-Cell Hybridomas. Elsevier/ North-Holland Biomedical Press, Amsterdam.

29. Thiele, D. L., and P. E. Lipsky. 1985. Regulation of cellular function by products of lysosomal enzyme activity: elimination of human natural killer cells by a dipeptide methyl ester generated from L-leucine methyl ester by monocytes or polymorphonuclear leukocytes. Proc. Natl. Acad. Sci. USA. 82:2468-2472.

30. Thiele, D. L., and P. E. Lipsky. 1985. Modulation of human natural killer cell function by L-leucine methyl ester: monocyte-dependent depletion from human peripheral blood mononuclear cells. $J$. Immunol. 134:786-793.

31. Thiele, D. L., J. A. Calomeni, and P. E. Lipsky. 1987. Leucylleucine methyl ester treatment of donor cells permits establishment of immunocompetent parent $\rightarrow F_{1}$ chimeras that are selectively tolerant of host alloantigens. J. Immunol. 139:2137-2142.

32. Golding, H., and A. Singer. 1985. Specificity, phenotype, and precursor frequency of primary cytolytic $\mathrm{T}$ lymphocytes specific for class II major histocompatibility antigens. J. Immunol. 135:16101615.

33. Thiele, D. L., S. E. Bryde, and P. E. Lipsky. 1988. Lethal graft-vs-host disease induced by a class II MHC antigen only disparity is not mediated by cytotoxic T cells. J. Immunol. 141:3377-3382.

34. Guy-Grand, D., and P. Vassalli. 1986. Gut injury in mouse graft-versus-host reaction: study of its occurrence and mechanisms. $J$. Clin. Invest. 77:1584-1595.

35. Mowat A. M., A. Borland, and D. M. V. Parrott. 1986. Hypersensitivity reactions in the small intestine. VII. Induction of the intestinal phase of murine graft-versus-host reaction by Lyt $2^{-} \mathrm{T}$ cells activated by I-A alloantigens. Transplantation (Baltimore). 41:192-198.

36. Piguet, P.-F., G. E. Grau, B. Allet, and P. Vassalli. 1987. Tumor necrosis factor/cachectin is an effector of skin and gut lesions of the acute phase of graft-vs.-host disease. J. Exp. Med. 166:1280-1289. 